\title{
IDENTIFIKASI FAUNA TANAH PADA AREAL PASCAPENAMBANGAN TANAH URUGAN SEBAGAI REKLAMASI LAHAN PERTANIAN DI DESA LENDANG NANGKA PROVINSI NUSA TENGGARA BARAT
}

\author{
Munawir Sazali \\ Dosen Jurusan Tadris IPA Biologi FITK IAIN Mataram
}

\begin{abstract}
Abstrak
Keberadaan mesofauna dan makrofauna tanah bisa dijadikan sebagai bioindikator kesuburan tanah. Keanekaragaman fauna tanah sangat ditentukan oleh sumber nutrisi berupa biomassa yang tersedia untuk keberlangsungan hidup. Tujuan dari penelitian ini untuk mengidentifikasi keanekaragaman spesies dari makrofauna dan mesofauna tanah serta hubungannya dengan faktor lingkungan (environment faktors) pasca penambangan tanah urugan di Desa Lendang Nangka. Manfaat penelitian ini untuk menyediakan informasi dan merekomendasikan langkah monitoring keberadaan mesofauna dan makrofauna tanah sebagai bioindikator kesuburan tanah, sehingga aktifitas reklamasi tanah pasca tambang sesuai dengan keinginan masyarakat. Hasil analisis data kekayaan jenis $\left(\mathrm{R}_{1}\right)$ dan keanekaragaman $\left(\mathrm{H}^{\prime}\right)$ pada masingmasing lokasi memiliki perbedaan, hal ini sangat dipengaruhi oleh lama waktu pasca tambang dan faktor fisika dan kimia tanah. $\mathrm{H}^{\prime}$ pada Lokasi I (Dusun Lendang Bagek/ tiga tahun pasca tambang) $=1,35<1,5$, menunjukkan diversitas fauna tanah yang rendah. Lokasi II (Desa Lendang Nangka Utara/ 9 tahun pasca tambang) dengan $H^{\prime}=2,01<3,5$ menunjukkan diversitas sedang dan kekayaan spesies yang tinggi.
\end{abstract}

Kata kunci: Fauna Tanah, Keanekaragaman Spesies, Faktor Edafis Tanah 


\section{PENDAHULUAN}

Lendang Nangka merupakan daerah pedesaan dengan wilayah persawahan, pemukiman dan lahan terbuka yang terletak antara $8^{\circ} 35^{\prime} 40.03^{\prime \prime S}$ dan $116^{\circ} 26^{\prime} 45.45 "$ E. Lahan terbuka ini terbentuk dari hasil penggalian tanah untuk dijadikan tanah urugan, dengan tujuan menjadikan lahan menjadi persawahan, namun banyaknya lahan pasca urugan tanah tersebut menjadi tidak produktif lagi. Beberapa permasalahan masyarakat mulai muncul, diantaranya lahan bekas urugan untuk direstorasi menjadi sawah atau perkebunan tidak seperti yang diharapkan. Berkaitan dengan permasalahan tersebut perubahan kandungan hara tanah dan hilangnya lapisan atas tanah mendorong erosi permukaan tanah (Affiati, 2011), serasah sebagai pelindung sekaligus simpanan hara sebelum terjadinya dekomposisi oleh organisme tanah sudah berkurang (Hilwan dan Handayani. 2013).

Berbagai fauna tanah melakukan konsorsium mengadakan perubahan-perubahan tekstur maupun komposisi tanah atas (top soil) . Akar-akar tanaman yang mati atau bagian tanaman lainnya dengan cepat dibusukkan oleh beberapa jenis decomposer, seperti jamur, bakteri dan golongan mesofauna dan makrofauna tanah (Lavelle, 1996; Sugiyarto dkk., 2007).

Keberadaan mesofauna dan makrofauna dalam tanah sangat tergantung pada ketersediaan energi dan sumber nutrisi (Whalen dan Hamel. 2004; Ruiz dan Lavelle. 2008), seperti bahan organik dan biomassa yang berkaitan dengan aliran siklus kaenergi dalam tanah. Ketersediaan energi dan nutrisi sangat mempengaruhi perkembangan dan aktivitas mesofauna dan makrofauna tanah sehingga memberikan dampak positif bagi kesuburan tanah (Arief 2001; Wulandari dkk., 2007).

Tujuan penelitian ini adalah ingin mengetahui keanekaragaman bioindikator mesofauna dan makrofauna tanah serta menganalisis faktor-faktor yang memengaruhi keberadaannya pada lahan bekas pertambangan tanah (tanah urugan). Adapun manfaat penelitian ini adalah memberikan informasi dan masukan guna memantau perkembangan keanekaragaman mesofauna dan makrofauna tanah dari bekas

118 BIOTA: Jurnal Tadris IPA Biologi FITK IAIN Mataram 
kegiatan pertambangan timah, serta perubahan-perubahan yang muncul pada sifat fisik tanah, sehingga dapat ditentukan perlakuan- perlakuan berikutnya untuk kegiatan reklamasi lahan bekas tambang timah.

\section{METODE}

\section{Waktu dan Tempat Penelitian}

Penelitian dilaksanakan di dua lokasi bekas tambang urugan tanah, yaitu: Lokasi I di Dusun Lendang Bagek, Desa Lendang Nangka Kecamatan Masbagik, telah 3 (tiga) tahun pasca tambang. Lokasi II di Desa Lendang Nangka Utara Kecamatan Masbagik, telah 9 (sembilan) tahun pasca tambang. Penelitian ini dilaksanakan pada bulan September-Desember 2015.

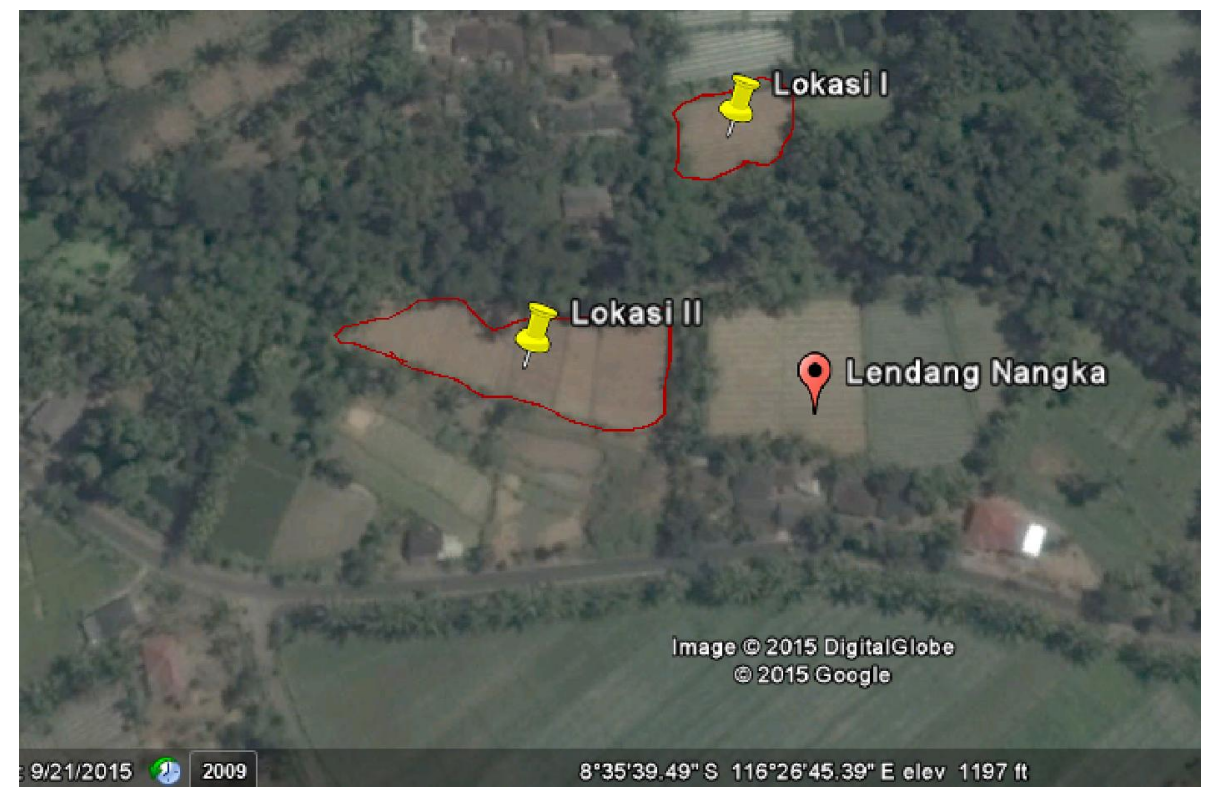

Gambar 1

Lokasi Penelitian 


\section{Instrumen Pengambilan data}

Alat-alat yang digunakan antara lain: toples kaca, corong plastik berukuran besar, lampu pijar 20 watt, $\mathrm{pH}$ meter (soil tester), hygrometer, kantong kain, pita meter, bak plastik (30 x 30 $\mathrm{cm}$ ), kantung kain, kertas label, cangkul, tali raffia, gelas ukur, sarung tangan plastik, Google Earth, kamera digital, kaca pembesar, irisan bambu $\left(1 \mathrm{~m}^{2}\right)$ dan alat tulis. Bahan yang digunakan terdiri dari akuades, deterjen, formalin 4\% dan alkohol 70\%. Data ditabulasi menggunakan Excell 2007 dan dianalisis menggunakan software PAST version 2.17.

\section{Prosedur pengambilan mesofauna dan makrofauna tanah (Berelse Tullgren Extractor)}

Koleksi mseofauna dan makrofauna tanah menggunakan Berlese Tullgren Extractor. Mengeruk secara cepat permukaan tanah pada kedalaman $10 \mathrm{~cm}$ dan menempatkannya pada bak plastik. Beberapa fauna tanah bisa langsung dikoleksi dengan menggoyangkan bak plastik dan memasukkannya ke dalam kantung plastik transparan. Sampel tanah dibawa ke dalam ruangan kemudian ditempatkan di atas berelese tullgren extractor. Mekanisme berelese tullgren extractor memanaskan tanah dengan bantuan lampu pijar 20 watt, fauna tanah akan bergerak menjauhi panas dan akan terjebak dalam toples kaca yang sudah terisi alkohol $70 \%$ dan formalin $4 \%$.

\section{Prosedur analisis sifat fisik dan faktor edafis tanah}

Tekstur tanah ditentukan dengan metode uji rasa rabaan. Mengambil setengah genggam contoh tanah, sehingga menyisakan pisahan tanah halus. Menambahkan sedikit air (jika tanahnya kering), membiarkannya terserap tanah, dikepal-kepal dan diuli dengan jari telunjuk dan ibu jari sampai merata dan hancur menjadi butiran-butiran. Menambahkan sampel tanah atau air jika keadaan contoh tanah terlalu basah atau kering, dilakukan pengulangan sampai contoh tanah jika ditingkatkan kebasahannya akan menempel pada jari-jari tangan.

120 BIOTA: Jurnal Tadris IPA Biologi FITK IAIN Mataram 
Tabel 1

Klasifikasi Struktur Fisik Tanah Untuk Penetapan di Lapangan

\begin{tabular}{|c|l|}
\hline $\begin{array}{c}\text { Struktur Fisik } \\
\text { Tanah }\end{array}$ & \multicolumn{1}{|c|}{ Uraian } \\
\hline Tidak berbentuk & $\begin{array}{l}\text { Tidak terlihatnya agregasi (pengumpulan), } \\
\text { atau adanya agregasi tetapi tidak } \\
\text { memperlihatkan adanya bidang belah } \\
\text { alami }\end{array}$ \\
\hline Lemah & $\begin{array}{l}\text { Struktur terbentuk sangat buruk dengan } \\
\text { batas yang tidak jelas. Jika tanah } \\
\text { dihancurkan maka akan terlihat seperti } \\
\text { tercampur. }\end{array}$ \\
\hline Sedang/cukup & $\begin{array}{l}\text { jika masa tanah direpih akan hancur } \\
\text { menjadi campuran, strukturnya utuh dan } \\
\text { masa tidak teragregasi baik itu sedikit } \\
\text { maupun tidak ada. }\end{array}$ \\
\hline Teguh & $\begin{array}{l}\text { Struktur kuat dibandingkan dari struktur } \\
\text { lain. Jika massa tanah dihancurkan: } \\
\text { struktunya akan hancur/patah dan massa } \\
\text { tidak teragregasi. }\end{array}$ \\
\hline
\end{tabular}

Sumber: Purwowidodo 2005

\section{Prosedur pengukuran sifat kimia tanah}

Penetapan besaran pH (kemasaman) suatu tanah dapat dilakukan dengan bantuan beberapa alat. Dalam penelitian ini alat yang digunakan berupa $\mathrm{pH}$ meter atau soil tester, mekanisme pengamatan dapat dilakukan langsung pada wilayah pengamatan dengan menancapkan bagian ujung soil tester dan akan menunjukkan kisaran keasaman $(\mathrm{pH})$ dari tanah yang diamati. Pedoman penentuan kisaran keasaman tanahditetapkan dengan menggunakan kriteria seperti pada Tabel 2 di bawah ini (Olson 1981 dalam Purwowidodo 2005). 
Tabel 2

Kategori Kemasaman/Kealkalian Tanah

\begin{tabular}{|c|l|c|}
\hline No & Kategori & Kisaran Besaran PH \\
\hline 1 & Luar biasa masam & $<4,4$ \\
\hline 2 & Sangat masam & $4,5-5,0$ \\
\hline 3 & Masam & $5,1-5,5$ \\
\hline 4 & Cukup masam & $5,6-6,0$ \\
\hline 5 & Agak masam & $6,1-6,5$ \\
\hline 6 & Netral & $6,6-7,3$ \\
\hline 7 & Agak alkalin & $7,4-7,8$ \\
\hline 8 & Cukup alkalin & $7,9-8,4$ \\
\hline 9 & Sangat alkalin & $8,5-9,0$ \\
\hline 10 & Luar biasa alkalin & $>9,0$ \\
\hline
\end{tabular}

\section{Prosedur pengukuran suhu dan temperatur}

Suhu tanah dan temperature dapat ditentukan dengan menggunakan instrument berupa thermometer dan hygrometer. Alat diletakkan di atas permukaan tanah setinggi $10 \mathrm{~cm}$ dengan mengukur kalibrasi selama 2 menit, pengambilan data suhu dan temperature dilakukan sebanyak 3 (tiga) kali; 08.00, 11.00 dan 16.00 .

\section{HASIL DAN PEMBAHASAN}

\section{Sifat Fisik dan Kimia Tanah}

Untuk sifat fisik tanah, kelas tekstur serta struktur tanah di 3 lokasi pengamatan berbeda-beda, seperti pada sifat kimia tanah keasaman tanah $(\mathrm{pH})$ berbeda pada masing-masing lokasi atau, kondisi edafis tanah menunjukkan sifat fisik tanah seperti jenis tanah, tekstur tanah dan kebasahan tanah (Begum dkk., 2014). Temperatur dan kelembaban terllihat nilai yang saling terbalik, seperti yang terlihat pada tabel 3 berikut.

122 BIOTA: Jurnal Tadris IPA Biologi FITK IAIN Mataram 
Tabel 3

Faktor Fisika dan Kimia Serta Posisi Pengamatan

\begin{tabular}{|c|c|c|c|c|c|c|c|}
\hline \multirow[b]{2}{*}{$\begin{array}{c}\text { Loka } \\
\text { si }\end{array}$} & \multirow{2}{*}{$\begin{array}{c}\text { Titik } \\
\text { Koordinat }\end{array}$} & \multirow[b]{2}{*}{$\begin{array}{c}\text { Kelembab } \\
\text { an }\end{array}$} & \multirow[b]{2}{*}{$\begin{array}{l}\text { Temper } \\
\text { atur }\end{array}$} & \multirow[b]{2}{*}{$\mathrm{pH}$} & \multicolumn{3}{|c|}{ Faktor Edafis Tanah } \\
\hline & & & & & Jenis & $\begin{array}{c}\text { Tekstu } \\
\mathrm{r}\end{array}$ & $\begin{array}{c}\text { Kebasah } \\
\text { an }\end{array}$ \\
\hline $\begin{array}{l}\text { Loka } \\
\text { si I }\end{array}$ & $\begin{array}{l}8^{\circ} 35^{\prime} 37.77^{\prime \prime} \\
S \\
116^{\circ} 26^{\prime} 44.5 \\
8^{\prime \prime} \mathrm{E} \\
\end{array}$ & $38 \%$ & $34^{\circ} \mathrm{C}$ & 5,9 & $\begin{array}{l}\text { Lempu } \\
\text { ng }\end{array}$ & $\begin{array}{l}\text { Berde } \\
\text { bu }\end{array}$ & Kering \\
\hline $\begin{array}{l}\text { Loka } \\
\text { si II }\end{array}$ & $\begin{array}{l}8^{\circ} 35^{\prime} 39.83^{\prime \prime} \\
\mathrm{S} \\
116^{\circ} 26^{\prime} 43.0 \\
0^{\prime \prime E}\end{array}$ & $51 \%$ & $30^{\circ} \mathrm{C}$ & 5,2 & $\begin{array}{l}\text { Lempu } \\
\text { ng }\end{array}$ & $\begin{array}{l}\text { Agreg } \\
\text { at }\end{array}$ & Kering \\
\hline
\end{tabular}

Data yang disajikan dalam tabel 3, menunjukkan gambaran kondisi fisik dari lingkungan pengamatan. Faktor edafis tanah terlihat ke dua lokasi merupakan lahan kering, berdebu dan tekstur tanah berbeda pada lokasi I dan II yang dibiarkan pasca penambangan tanah urugan.

\section{Keanekaragaman Mesofauna dan Makrofauna Tanah}

Mesofauna dan makrofauna tanah di dua lokasi pengamatan memiliki perbedaan dalam penyebaran dan populasi, kondisi dan lama waktu masa tabang tanah memberikan pengaruh besar keberadaan fauna tanah, seperti yang terlihat pada Tabel 4 .

\section{Tabel 4}

Jenis Mesofauna dan Makrofauna Tanah

\begin{tabular}{|c|c|c|c|c|c|}
\hline \multirow{2}{*}{ NO } & \multicolumn{2}{|c|}{ Jenis Mesofauna dan Makrofauna Tanah } & \multicolumn{2}{|c|}{ Lokasi } & \multirow{2}{*}{ Keterangan } \\
\hline & Nama Ilmiah & Nama Lokal & I & II & \\
\hline 1 & $\begin{array}{l}\text { Formica cinera } \\
\text { (Mayr) }\end{array}$ & Semut Merah & 21 & 63 & Makrofauna \\
\hline 2 & Colembolla sp. & Colembolla & 17 & 49 & Mesofauna \\
\hline 3 & $\begin{array}{l}\text { Neotermes } \\
\text { (Holmgre) }\end{array}$ & Rayap tanah & 17 & 32 & Mesofauna \\
\hline 4 & $\begin{array}{l}\text { Polyrhachis dives } \\
\text { (Smith) }\end{array}$ & Semut Hitam & 14 & 27 & Makrofauna \\
\hline
\end{tabular}




\begin{tabular}{|c|c|c|c|c|c|}
\hline 5 & \begin{tabular}{|l|} 
Pholcus \\
phalangioides \\
(Fuesslin) \\
\end{tabular} & $\begin{array}{l}\text { Laba-laba } \\
\text { Pelompat }\end{array}$ & 12 & 23 & Makrofauna \\
\hline 6 & $\begin{array}{l}\text { Lumbricus terestris } \\
\text { (L.) }\end{array}$ & Cacing Tanah & 10 & 18 & Makrofauna \\
\hline 7 & $\begin{array}{ll}\begin{array}{l}\text { Phyllophaga } \\
\text { (Linnaeus) }\end{array} & s p . \\
\end{array}$ & Kumbang & 9 & 18 & Makrofauna \\
\hline 8 & - & Larfa & 8 & 16 & Mesofauna \\
\hline 9 & $\begin{array}{l}\text { Pachymerium } \\
\text { ferrugineum (C. L. } \\
\text { Koch) }\end{array}$ & Kelabang & 8 & 13 & Makrofauna \\
\hline 10 & - & Ngengat & 6 & 9 & Makrofauna \\
\hline 11 & $\begin{array}{l}\text { Myrmeleon } \\
\text { formicarius (L.) }\end{array}$ & Undur-undur & 3 & 7 & Makrofauna \\
\hline 12 & $\begin{array}{l}\text { Odontomachus } \\
\text { rixosus (Smith, F.) }\end{array}$ & Semut Bertanduk & 1 & 7 & Makrofauna \\
\hline 13 & - & Jangkri & 1 & 3 & Makrofauna \\
\hline 14 & - & Unidentification & - & 2 & Mesofauna \\
\hline
\end{tabular}

Berdasarkan Tabel 4, diketahui jumlah jenis makrofauna tanah (10 spesies) lebih banyak dibandingkan dengan mesofauna tanah (4 spesies). Sugiyarto dkk (2007) dan Sayad dkk (2012), menjelaskan makrofauna tanah berperan penting dalam dekomposisi bahan organik tanah guna menyediakan unsur hara. Makrofauna akan memecah menjadi lebih sederhana substansi nabati yang mati kemudian bahan tersebut dikeluarkan dalam bentuk kotoran yang kita kenal sebagai bahan humus. Bahan humus tersebut kemudian akan ditumbuhi oleh berbagai jenis mikroba yang melakukan konsorsium untuk menguraikan dengan bantuan enzim spesifik, sehingga terjadi proses dekomposisi bahan mineral yang bisa dimanfaatkan langsung oleh organisme lain (Whalen dan Hamel. 2004).

Beberapa jenis makrofauna tanah tidak hanya mampu melapukkan (memecah) bahan organik, tepai juga mampu merangsang kehadiran beberapa jenis mikroba untuk berasosiasi mempercepat proses dekompisisi. Kondisi lahan pengamatan dengan tingkat pH 52 (masam) dan pH 59 (cukup masam) disebut sebagai lahan miskin hara dengan ciri kandungan organik tanah yang kurang memadai. Jenis fauna tanah didominasi oleh beberapa jenis semut, cacing enchytracid, collembola yang

124 BIOTA: Jurnal Tadris IPA Biologi FITK IAIN Mataram 
berasosiasi dengan cendawan, serta beberapa larva serangga yang mendiami bagian dalam tanah.

Keberadaan mesofauna tanah sangat bergantung pada ketersediaan energi dan sumber nutrisi untuk melangsungkan hidupnya, seperti bahan organik dan biomassa yang semuanya berkaitan dengan aliran siklus karbon dalam tanah. Ketersediaan nutrisi bagi mesofauna tanah tentu memberikan dampak positif untuk perkembangan dan aktifitas mesofauna tanah serta menjaga keseuburan tanah dilokasi tersebut. Berdasarkan Tabel 4 menunjukkan jenis mesofauna tanah yang ditemukan dari lokasi penelitian sangat kurang. Kondisi mesofauna tanah seperti ini tentu dipengaruhi oleh ketersedian makanan sebagai sumber energi dan kondisi fisika kimia tanah yang mendukung untuk keberlangsungan mesofauna tanah (Djuuna, 2013).

Mesofauna tanah hidup secara berkelompok (colony) memiliki tingkat aktifitas lebih tinggi. Rayap tanah Neotermes sp. (Holmgre) pada hakikatnya hidup di dalam tanah dengan sistem yang tertutup, proses siklus makan-memakan (predasi) individu yang menyebabkan terjadinya pelumatan dan pengunyahan (ingested) sehingga terjadi penambahan senyawa organik yang dikenal sebagai produksi sekunder (alates). Tidak hanya itu rayap tanah juga memiliki peran sebagai dekomposer primer dari sisa pelapukan tumbuhan di permukaan tanah dan perombakan humus di dalam tanah.

Peranan fauna tanah lainnya, seperti cacing tanah dan semut mampu mempertahankan produktivitas tanah secara langsung. Respirasi dan mineralisasi melalui interaksi dengan fauna tanah yang lainmenentukan immobilisasi, pelepasan dan penyimpanan unsur hara, serta bahan organik di dalam tanah. Selain meningkatkan kesuburan dan mineralisasi tanah, jenis makrofauna ini juga membentuk agregasi tanah dan tekstur pori tanah lebih besar sehingga sirkulasi udara dan air bisa meningkat ke dalam tanah. 


\section{Indeks Keanekaragaman ( $\left.H^{\prime}\right)$ dan Kekayaan Jenis $\left(\mathrm{R}_{1}\right)$}

Keberadaan mesofauna dan makrofauna sangat menentukan tingkat kesuburan tanah, hasil koleksi beberapa jenis fauna tanah pada lokasi I (Dusun Lendang Bagek) menunjukkan tingkat keragaman dari spesies lebih rendah dibandingkan dengan lokasi II (Desa Lendang Nangka Utara). Hal ini sangat dipengaruhi oleh rentang waktu setelah pasca tambang seperti yang ditunjukkan pada tabel. 5

Tabel 5

Indeks Kekayaan dan Keanekaragaman Mesofauna dan Makrofauna Tanah

\begin{tabular}{|l|l|l|l|l|l|l|}
\hline No & Lokasi & $\begin{array}{l}\text { Lama waktu } \\
\text { pasca urugan (th) }\end{array}$ & $\mathrm{N}$ & $\mathrm{D}$ & $\mathrm{R}_{1}$ & $\mathrm{H}^{\prime}$ \\
\hline 1 & Dusun Lendang Bagek & 3 & 127 & 0,11 & 0,87 & 1,35 \\
\hline 2 & $\begin{array}{l}\text { Desa Lendang Nangka } \\
\text { Utara }\end{array}$ & 9 & 287 & 0,12 & 1,77 & 2,01 \\
\hline
\end{tabular}

Perbedaan jumlah spesies fauna tanah pada berbagai kondisi lahan disebabkan oleh adanya perbedaan kondisi edafis tanah serta faktor fisiko kimia dari masing lokasi. Pada tabel menunjukkan bahwa jumlah spesies dan kerapatan individu lebih tinggi pada lokasi II (Desa Lendang Nangka Utara) dibandingkan dengan lokasi I (Dusun Lendang Bagek).

Indeks keanekaragaman jenis $\left(\mathrm{H}^{\prime}\right)$ fauna tanah bervariasi. Nilai $H^{\prime}$ berkisar antara 1,5-3,5. Nilai $H^{\prime}<1,5$ menunjukkan keanekaragaman yang rendah, $1,5<\mathrm{H}^{\prime}<3,5$ menunjukkan keanekaragaman sedang, dan $\mathrm{H}^{\prime}>3,5$ menunjukkan keanekaragaman yang tinggi (Angreini 2002). Nilai H' sedang ditemukan di Lokasi II (Desa Lendang Nangka Utara) dengan nilai 2,01, sedangkan lokasi I (Dusun Lendang Bagek) kisaran nilai keanekaragaman (diversity index) rendah dengan nilai 1,35. Keanekaragaman Jenis $\left(\mathrm{H}^{\prime}\right)$ juga sangat dipengaruhi oleh faktor waktu yaitu rentang waktu pasca tambang urugan tanah. Faktor waktu ini berkaitan erat dengan tipe vegetasi yang akan tumbuh dan berkembang di atasnya.

126 ВIOTA: Jurnal Tadris IPA Biologi FITK IAIN Mataram 
Oleh karena itu, keberadaan mesofauna dan makrofauna sangat ditentukan oleh faktor pendukung pada suatu lokasi, lama waktu pasca tambang urugan serta tidak mendapatkan gangguan berupa penambangan lagi seperti terlihat pada tabel 5 menunjukkan kekayaan dan keanekaragaman lebih tinggi pada lokasi II (9 tahun) pasca tambang dibandingkan dengan lokasi I (3 tahun) pasca tambang.

\section{PENUTUP}

\section{Kesimpulan}

Mesofauna dan makrofauna tanah sebagai bioindikator memiliki peranan penting menjaga kesuburan tanah. Ketersediaan sumber nutrisi dan biomassa di dalam tanah menjadi faktor penting keberadaan mesofauna dan makrofauna tanah. Lama waktu psaca tambang terkait dengan perkembangan vegetasi di atas bekas lahan urugan serta perubahan sifat fisik dan kimia tanah, sangat menentukan tingkat keanekaragaman jenis fauna tanah (mesofauna dan makrofauna). Lokasi II (Desa Lendang Nangka Utara) dengan $\mathrm{H}^{\prime}=2,01<3,5$ menunjukkan diversitas sedang dan kekayaan spesies yang tinggi, sedangkan pada Lokasi I (Dusun Lendang Bagek) dengan $H^{\prime}=1,35<1,5$ menunjukkan diversitas fauna tanah yang rendah.

\section{Saran}

Penelitian ini masih dalam tahap awal, sehingga diperlukan penelitian lanjutan guna melihat secara menyeluruh dari kandungan organik tanah dan faktor-faktor lingkungan lainnya yang dapat mempengaruhi keberadaan mesofauna dan makrofauna sebagai bioindikator kesuburan tanah. 


\section{DAFTAR PUSTAKA}

Affiati Sofia Noor. 2011. Keanekaragaman Mesofauna dan Makrofauna Tanah pada Lahan Penambangan Pasir di Kawasan Lereng Gunung Merapi Kecamatan Kemalang, Kabupaten Klaten [Skripsi]. Fakultas Matematika dan Ilmu Pengetahuan Alam Universitas Sebelas Maret Surakarta.

Arief A. 2001. Hutan \& Kehutanan. Yogyakarta: Kanisius.

Begum Farida, dkk. 2014. Study of Soil Macrofauna in Relation with Some of Selected Soil Physio-Chemical Properties at Sumayar-Nagar in District Hunzanagar Gilgit-Baltistan, Pakistan. Journal of Biodiversity and Environmental Sciences (JBES). Vol (5) 3: 124-132.

Hilwan dan Handayani. 2013. Keanekaragaman Mesofauna dan Makrofauna Tanah pada Areal Bekas Tambang Timah di Kabupaten Belitung Provinsi Kepulauan Bangka-Belitung. Jurnal Silvikultur Tropika. Vol 4 (1): 35-41.

Lavelle P. 1996. Diversity of Soil Fauna and Ecosystem Function. Biologi International No33. Paris University.

Ruiz N and Lavelle P. 2008. Soil Macrofauna Field Manual. Food and Agriculture Organization of The United Nations. Rome.

Sayad E. dkk. Soil Macrofauna in Relation to Soil and Leaf Litter Properties in Tree Plantations. Journal of Forest Science. Vol (4): $170-180$.

Sugiyarto dkk. 2007. Preferency of Soil Macrofauna to Cropsresidue at Different Light Intensity. Jurnal Biodiversitas. Vol 8 (2): 96-100.

Purwowidodo. 1986. Tanah dan Erosi. Bogor: Kenari.

Whalen Joann K. and Hamel Chantal. 2004. Effects of Key Soil Organisms on Nutrient Dynamics in Temperate Agroecosystems. The Haworth Press. http://www.haworthpress.com/web/ICRIP

Wulandari Suteni dkk. 2007. Pengaruh Keanekaragaman Mesofauna dan Makrofauna Tanah terhadap Dekomposisi Bahan Organik Tanaman di Bawah Tegakan Sengon (Paraserianthes falcataria). Jurnal Bioteknologi. Vol 4 (1): 20-27.

128 BIOTA: Jurnal Tadris IPA Biologi FITK IAIN Mataram 